\title{
YouTube as a Source of Patient Information for Knee Osteoarthritis Exercises
}

\author{
Diz Osteoartriti Egzersizlerinde Hastalara Bilgi Kaynağı Olarak YouTube
}

(D) Fatih Bağcıer, (D) Elem Yorulmaz*, (D) Mustafa Hüseyin Temel*

\begin{abstract}
Biruni University Faculty of Medicine, Departmant of Physical Medicine and Rehabilitation, Istanbul, Turkey * University of Health Sciences Turkey, Istanbul Haydarpaşa Numune Training and Research Hospital, Clinic of Physical Medicine and Rehabilitation,

\section{Abstract}

Objective: Exercise therapy is the most important approach in knee osteoarthritis (OA). This study aimed to analyze the quality and reliability of exercises related to knee OA treatment found on the YouTube platform and contribute to this field, which have popularity in the literature. Materials and Methods: The keywords "knee osteoarthritis exercises," "knee osteoarthritis rehabilitation," "knee osteoarthritis physiotherapy," and "knee osteoarthritis physical therapy" were searched on YouTube on June 3, 2020. According to the global quality scale, the educational quality of YouTube videos was evaluated as high quality, intermediate, and low quality. The reliability of the videos was evaluated with the modified DISCERN score. Video source, upload date, and the number of views, likes, and dislikes parameters were documented. These parameters were compared between the groups.

Results: Of the 130 evaluated videos, $46.2 \%(n=60)$ were of high quality, wherein $38.3 \%(n=23)$ were uploaded by non-physician health personnel. No low-quality video was uploaded by physicians. High-quality videos were uploaded more recently than intermediate and low-quality videos $(p<0.05)$. Additionally, the video duration in the high-quality video group was significantly higher than the medium and low-quality videos $(p<0.05)$. The modified DISCERN score was found to be significantly higher in the high-quality video group. The modified DISCERN score of intermediate quality videos was significantly higher than the group of low-quality videos $(p<0.05)$

Conclusion: YouTube can be considered as a source with quality and reliable content in exercise videos related to knee OA treatment. Physicians who have the highest potential to produce quality videos should be encouraged to produce more videos.

Keywords: Knee osteoarthritis, YouTube, exercise

\section{Öz}

Amaç: Egzersiz diz osteoartritinde (OA) en önemli tedavi yaklaşımıdır. Bu çalışma, YouTube platformunda bulunan diz OA tedavisi ile ilgili egzersizlerin kalite ve güvenilirliğini analiz etmeyi ve literatürde popülerliği olan bu alana katkı sağlamayı amaçlamıştır.

Gereç ve Yöntem: "Knee osteoarthritis exercises", "knee osteoarthritis rehabilitation", "knee osteoarthritis physiotherapy" ve "knee osteoarthritis physical therapy" anahtar kelimeleri 3 Nisan 2020 tarihinde YouTube'da arandı. Videoların kalitesi global kalite skalası ile değerlendirildi ve yüksek, orta ve düşük kalite olmak üzere gruplandırıldı. Videoların güvenilirliği modifiye DISCERN skoru ile değerlendirildi. Video kaynağı, yüklenme tarihi, izlenme sayısı, beğeni ve beğenilmeme parametreleri dökümente edildi. Bu parametreler gruplar arasında karşılaştıııldı.

Bulgular: Incelenen 130 videodan \%46,2'si (n=60) yüksek kaliteli idi ve bu videoların \%38,3'i (n=23) doktor olmayan sağlık personeli tarafından yüklenmişti. Doktorların yüklediği hiçbir video düşük kaliteli olarak değerlendirilmedi. Yüksek kaliteli videoların orta ve düşük kaliteli videolara göre daha yakın tarihlerde yüklendiği görüldü $(p<0,05)$. Ayrıca video süreleri yüksek kaliteli videolarda orta ve düşük kaliteli videolara göre daha uzundu $(p<0,05)$. Modifiye DISCERN skorları yüksek kaliteli video grubunda orta ve düşük kaliteli video grubuna göre istatistiksel olarak anlamlı şekilde daha yüksek bulundu $(p<0,05)$.

Sonuç: Diz OA tedavisi ile ilgili egzersiz videolarında YouTube kaliteli ve güvenilir içeriğe sahip bir kaynak olarak değerlendirilebilir. Yüksek kaliteli videoları üretme potansiyeli en yüksek grup olan doktorlar daha fazla video üretmeleri için teşvik edilmelidir.

Anahtar kelimeler: Diz osteoartriti, YouTube, egzersiz

Address for Correspondence/Yazışma Adresi: Fatih Bağcıer PhD., Biruni University Faculty of Medicine, Departmant of Physical Medicine and Rehabilitation, İstanbul, Turkey Phone: +90 5442429042 E-mail: bagcier442@hotmail.com ORCID ID: orcid.org/0000-0002-6103-7873

Received/Geliş Tarihi: 11.08.2020 Accepted/Kabul Tarihi: 21.01.2021

${ }^{\circ}$ Copyright 2021 by the Turkish Osteoporosis Society / Turkish Journal of Osteoporosis published by Galenos Publishing House. 


\section{Introduction}

Knee osteoarthritis (OA) is the most common form of OA (1). Its treatment aims to control pain, correct and maintain joint functions, ensure functional independence, and improve the quality of life (1). Exercise therapy is the most important therapeutic approach with a proven effect on knee OA. It has been reported that quadriceps strengthening exercises, joint range of motion exercises, flexibility exercises, and aerobic exercises increase functionality parameters, improve quality of life and pain scores (2).

It should not be forgotten that in the etiology of knee OA, there is muscle weakness or dysfunction as a result of not exercising, as well as sports activities resulting in overuse injuries (3). Therefore, the importance of doing correct exercise should be understood instead of doing exercise (3). At this point, patients should take care to perform their exercises correctly, at the appropriate frequency and time. One way to learn how to do the correct exercises can also be web-based programs (4). In a study in patients with knee and/or hip OA; significant improvements in symptoms, physical activity and function, and quality of life were determined with an internet-based exercise program compared to the control group on the waiting list (4). The internet has become the largest and most updated source of reference for health issues (5-7). People who are well-informed about health-related issues are more active in managing their health status, increasing their quality of life. The contribution of self-management is important for patients' well-being, especially in chronic diseases (8). YouTube is a popular social platform on the Internet, easy-to-use with free access, and is often visited by those seeking healthcare information (9). YouTube videos contain visual, auditory, and written information on health shared by people, organizations, hospitals, and academic institutions worldwide (5). This platform hosts approximately $60 \%$ of all videos on the internet; 100 million videos are watched on YouTube daily, which indicates a great potential for easily accessible information on diseases, diagnoses, and treatment approaches (10). However, it is of concern that anyone can upload videos; the uploaded videos may serve profit-making purposes, and the protocols for control are inadequate for content analyses. Therefore, the accuracy, quality, and reliability of healthcare data obtained from YouTube should be carefully analyzed (11).

The quality and reliability of videos on YouTube regarding many diseases and treatment methods have been evaluated (10-14). However, no study has analyzed videos on knee OA. This study aimed to evaluate the quality and reliability of videos related to knee OA exercises on YouTube and contribute to the existing literature.

\section{Materials and Methods}

On June 3, 2020, we searched YouTube using the keywords "knee OA exercises," "knee OA rehabilitation," "knee OA physiotherapy," and "knee OA physical therapy." It has been observed that the majority of YouTube users view the first three pages of a search result; thus, for this study, we examined the first 60 English videos that showed as a result of each keyword search (15). A total of 240 videos resulted from four keyword searches; those that were irrelevant to the topic, not in English, and those with issues of sound or image quality were excluded from the study. We studied the remaining 130 videos.

\section{Quality Evaluation}

The quality of the videos was evaluated by two independent investigators (F.B., M.H.T.) using global quality scale (GQS). In case of inconsistencies, a third investigator (E.I.Y.) was consulted. The videos were evaluated based on the GQS score consisting of a 5-point scale according to the following criteria: ease of use, visual-audio quality, and intelligibility. Videos with a GQS score of 1 and 2 points were classified as low-quality, 3 points as intermediate-quality, and 4 and 5 points as high-quality (Table 1) (16).

\section{Reliability Evaluation}

The reliability of the videos included in the study was assessed using the modified DISCERN scale. The scale consisted of five questions that were answered with a "yes" or " $\mathrm{n}$ " and each "yes" answer was recorded as 1 point. The highest and lowest scores on the modified DISCERN scale were 5 and 0 , respectively (Table 1) (17).

\section{Video-related Parameters}

We recorded for how long the videos had been on YouTube. In addition, the date of upload, number of views, likes, and dislikes were documented. Moreover, the numbers of daily views, daily reviews, and daily likes were also calculated.

\section{Video Source}

We used Cohen's kappa (к) to determine the inter-reviewer agreement for video categorization. The videos were categorized by two independent investigators (F.B., M.H.T.). In case of inconsistencies, a third researcher (E.I.Y.) was consulted. The categories included non-physician healthcare personnel, physicians, academia/universities, healthcare-related websites, and patient/independent users.

\section{Ethics Committee}

This study did not include any humans or animals; therefore, we did not apply for ethical approval or register for clinical trials $(18,19)$.

\section{Statistical Analysis}

The mean, standard deviation, median, lowest value, highest value, frequency, and ratios were used to statistically analyze the data. The distribution of variables was measured using the Kolmogorov-Smirnov test. The Kruskal-Wallis and Mann-Whitney $U$ tests were used to analyze quantitative independent data along with the chi-square test and Fisher's exact test, when the conditions for the chi-square test were not met. The SPSS 26.0 program was used for the analyses. The inter-reviewer 
agreement analysis for determining video categorization was almost excellent [Cohen's $\kappa$ coefficient $=0.924$ ]

\section{Results}

Of the 240 videos that were screened, a total of 130 unique English videos with a total of 46,618,196 views and total duration of 848.25 min were selected for further analysis (Figure 1). The general characteristics of the videos are presented in Table 2. According to the GQS score, $46.2 \%(n=60)$ of the videos were high-quality, 36.2\% ( $n=47)$ were intermediate quality, and $17.7 \%(n=23)$ were low-quality videos. Of the highquality videos, $38.3 \%$ of $(n=23)$ were uploaded by non-physician healthcare personnel, 31.7\% $(n=19)$ by academia/universityrelated sources, $23.3 \%(n=14)$ by physicians, and $6.7 \%(n=4)$ by healthcare-related websites. Of the low-quality videos, $52.2 \%$ $(n=12)$ were uploaded by academia/university-related sources, $34.8 \%(n=8)$ by non-physician healthcare personnel, and $13 \%$ $(n=3)$ by healthcare-related websites. There were no low-quality videos uploaded by physicians, and no videos were uploaded by

Table 1. Assessment tools for reliability, and global quality scale of knee osteoarthritis exercises videos on YouTube

Reliability (1 point per question answered yes)

1. Is the video clear, concise, and understandable?

2. Are valid sources cited? (from valid studies, physiatrists or rheumatologists)

3. Is the information provided balanced and unbiased?

4. Are additional sources of information listed for patient reference?

5. Does the video address areas of controversy/uncertainty?

\section{Global quality scale}

1. Poor quality, poor flow, most information missing, not helpful for patients

2. Generally poor, some information given but of limited use to patients

3. Moderate quality, some important information is adequately discussed

4. Good quality good flow, most relevant information is covered, useful for patients

5. Excellent quality and excellent flow, very useful for patients

Table 2. General features of the videos

\begin{tabular}{|c|c|c|c|c|}
\hline \multicolumn{2}{|l|}{ Parameters } & Min-max & Median & Mean \pm SD/n (\%) \\
\hline \multicolumn{2}{|l|}{ Video duration on youtube (month) } & 7.0-120.0 & 49.0 & $52.1 \pm 28.0$ \\
\hline \multicolumn{2}{|l|}{ Duration (s) } & $39.0-2023,0$ & 273.5 & $391.5 \pm 369.2$ \\
\hline \multicolumn{5}{|l|}{ Source } \\
\hline \multicolumn{2}{|l|}{ Non-physician health personnel } & - & - & $43(33.1 \%)$ \\
\hline \multicolumn{2}{|l|}{ Physician } & - & - & $21(16.2 \%)$ \\
\hline \multicolumn{2}{|l|}{ Academic/university } & - & - & $54(41.5 \%)$ \\
\hline \multicolumn{2}{|l|}{ Health-related website } & - & - & $12(9.2 \%)$ \\
\hline \multirow{3}{*}{ Quality } & Low & - & - & $23(17.7 \%)$ \\
\hline & Intermediate & - & - & $47(36.2 \%)$ \\
\hline & High & - & - & $60(46.2 \%)$ \\
\hline \multicolumn{2}{|l|}{ Number of views } & $1000,0-3353300,0$ & 67250,0 & $358580,0 \pm 587740,0$ \\
\hline \multicolumn{2}{|l|}{ Number of likes } & $0.0-63000,0$ & 378.5 & $4124,0 \pm 8332,7$ \\
\hline \multicolumn{2}{|l|}{ Number of dislikes } & $0.0-2300,0$ & 20.0 & $168.7 \pm 342.5$ \\
\hline \multicolumn{2}{|l|}{ Number of comments } & $0.0-2490,0$ & 19.0 & $133.1 \pm 285.7$ \\
\hline \multicolumn{2}{|l|}{ GQS score } & $1.0-5.0$ & 3.0 & $3.4 \pm 0.9$ \\
\hline \multicolumn{2}{|l|}{ Like per day } & $0.0-75.0$ & 0.4 & $4.0 \pm 10.3$ \\
\hline \multicolumn{2}{|l|}{ Dislike per day } & 0.0-3.7 & 0.0 & $0.2 \pm 0.6$ \\
\hline \multicolumn{2}{|l|}{ Comment per day } & $0.0-2.3$ & 0.0 & $0.1 \pm 0.3$ \\
\hline \multicolumn{2}{|l|}{ View per day } & $0.0-5.3$ & 0.0 & $0.3 \pm 0.7$ \\
\hline \multicolumn{2}{|l|}{ DISCERN score } & $1.0-5.0$ & 3.0 & $2.9 \pm 0.9$ \\
\hline
\end{tabular}


patients/independent users. It was observed that among the groups that uploaded videos, physicians uploaded videos with a statistically higher quality than the other groups $(p<0.05)$. High-quality videos were uploaded more recently than intermediate and low-quality videos $(p<0.05)$. The high-quality videos were significantly longer than intermediate and lowquality videos $(p<0.05)$. Intermediate-quality videos were also significantly longer than low-quality videos $(p<0.05)$. The modified DISCERN score was significantly the highest for high-quality videos, whereas the scores of intermediate-quality videos were significantly higher than those of low-quality videos $(p<0.05)$.

While high- and intermediate-quality videos were viewed significantly more than lowquality videos $(p<0.05)$, there was no significant difference between the number of views of high and intermediate-quality videos. The numbers of comments and likes of highquality videos were significantly higher, their number of dislikes was significantly lower than those of intermediate- and low-quality videos $(p<0.05)$. The numbers of comments and likes of intermediate-quality videos were significantly higher than those of low-quality videos; and their number of dislikes was significantly lower $(p<0.05)$. The distribution of data according to the quality of videos is given in Table 3.

\section{Discussion}

Social media offers many innovations in the fields of healthcare and communication; thus, it provides a different dimension to the communication between healthcare professionals and patients (20). YouTube, a popular social media platform, is the third most accessed website worldwide and quickly delivers content to large masses (21).

This platform, where an average of 100 million videos are viewed per day, is at the forefront for researching healthcare-related information on the Internet and social media. Unfortunately, there is also a risk of spreading false information because there are no filters at the stage of upload (18). Indeed, there is no standard algorithm on YouTube that controls the quality and reliability of healthcare-related videos. Studies have reported the quality and reliability of YouTube videos on different

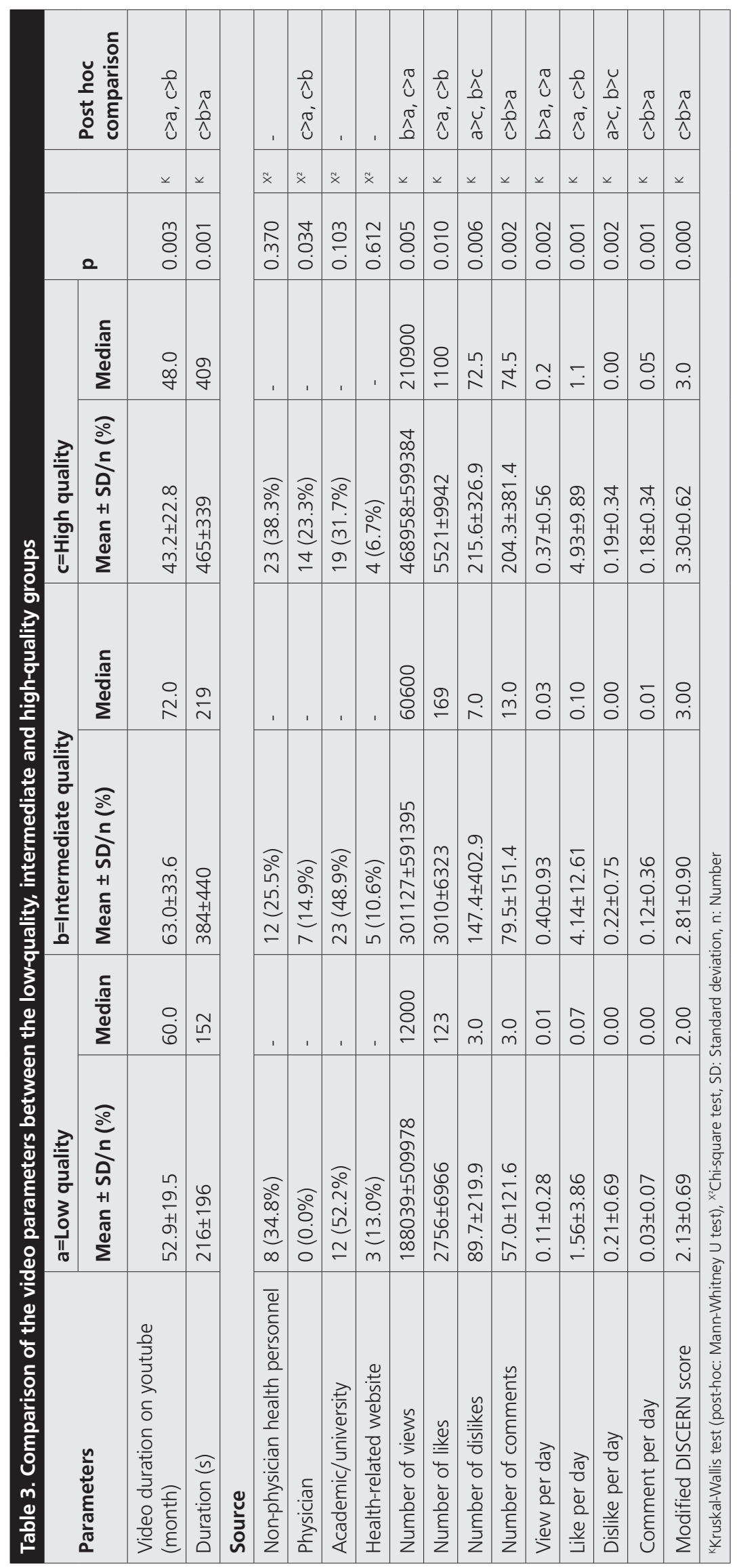




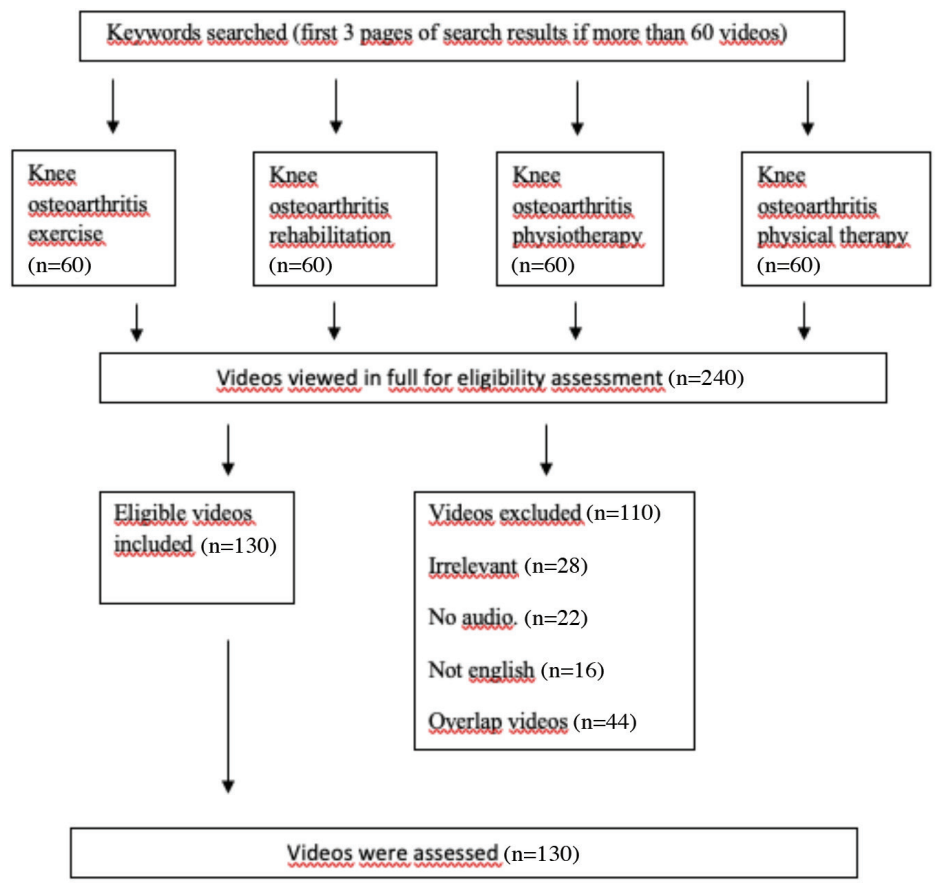

Figure 1. Selection of eligible YouTube videos for the study

diseases (22-24). This is the first study to assess the quality and reliability of YouTube videos on exercise therapy for the treatment of knee OA.

This study revealed that videos on exercise for knee OA are considerably popular on YouTube, with an average of 358,580 views. Video reviews have been reported on popular topics related to healthcare, such as disc herniation and rotator cuff tear, but the number of views was smaller than that of video reviews on topics including exercises for ankylosing spondylitis, anterior cruciate ligament damage and its repair, anti- tumour necrosis factor (TNF) injections, knee OA and arthroplasty, and kyphosis (18,24-27).

These results suggest that medical information on these subjects is insufficiently provided by professionals compared to other fields, and patients attempt to fill this gap with information obtained from social media. Therefore, we believe that professionals should increase the provision of available data on exercise for knee OA for patients. The average duration of the videos evaluated in this study was $6.5 \mathrm{~min}$. YouTube video times related to orthopedic diagnoses have been reported to vary between 5 and $10 \mathrm{~min}$, consistent with the data in the present study $(23,24,26-29)$. A study on exercise for ankylosing spondylitis also revealed similar video durations. These data show that providers on YouTube prefer an average duration that is sufficient to provide information on a healthcare-related topic while maintaining the viewers' attention.

Studies evaluating YouTube videos classified references in many different ways. Nevertheless, similar to the present study, most videos were broadcasted by physicians, non-physician healthcare personnel, and academia/university-related sources; videos uploaded by patients/individual users were few in number $(22,23,25,30,31)$. In contrast to the general data, patient/ individual users uploading videos related to anti-TNF applications was approximately $80 \%$. We believe this is because patients can often share their experiences with anti-TNF injections. In the present study, no videos of patient origin were found. This finding is probably associated with the age of the population that is generally affected by knee OA. It may be considered that this age group is less likely to use social media platforms as a producer.

In this study, videos were evaluated according to their GQS scores; $17.7 \%(n=23)$ of the videos were found to be of low-quality, $36.2 \%(n=47)$ were of intermediate-quality, and $46.2 \%(n=60)$ of high-quality. Although low-quality videos were often found in YouTube studies conducted on similar orthopedic diagnoses $(22,23,26,28,31)$, studies have also reported videos with a similar quality or usefulness related to the present study $(18,25)$. In particular, Kocyigit et al. (25) evaluated YouTube videos on exercises for ankylosing spondylitis, using a methodology similar to the present study; they reported that $48.2 \%$ of the videos were of high-quality. Methodological variations, such as studies conducted on different diseases, differences in the numbers of videos analyzed, and the use of different evaluation methods, may explain this difference.

The high-quality videos evaluated in our study were primarily uploaded by non-physicians and academia/university-related sources. It may be associated with the large number of videos that these two groups upload. In fact, it was found that lowquality videos were also uploaded primarily by non-physicians and academia/university-related sources. The inconsistency in 
the quality of non-physicians' videos may be a reflection of the difference in the level of knowledge of uploaders on exercise and sports physiology.

The usefulness or quality of videos uploaded by academia/ university-related sources was observed at different rates in the literature. In a study on kidney stones, useful videos were available at a rate of $8.6 \%$ (6), whereas in a study of ankylosing spondylitis exercises, the rate of useful videos was $72.7 \%$ (25). Besides, Tolu et al. (18) and Kocyigit et al. (25) did not find any low-quality videos uploaded by academia/university-related sources in their study. In the present study, the numbers of low- and high-quality videos uploaded by academia/universityrelated sources were almost similar. Given that the creators of videos in this group may have different academic positions (physician/non-physician), this result may reflect the quality variability observed in non-physician videos. Nevertheless, we believe that universities, which are obliged, in our opinion, to provide the most reliable healthcare information, should be encouraged to make more qualified shares associated with exercises in knee OA. It was found that physicians uploaded $23.3 \%$ of the high-quality videos and did not upload any lowquality videos. It is consistent with previous literature data $(13,32)$ and suggests that doctors should be encouraged to be more involved in this rapidly developing field. Indeed, there is a need for both high-quality and large numbers of videos for knee OA.

Unlike previous literature data, it was observed that the high-quality videos were more recently uploaded than intermediate- and low-quality videos; also, they were watched more frequently, received more comments, more likes, and few dislikes, and the duration of videos was longer. Moreover, the modified DISCERN score was significantly higher in the group of high-quality videos, which means that high-quality videos were more reliable. More recently uploaded high-quality videos may indicate an increasing awareness of the potential of YouTube and that more qualified content is gradually being made available. Again, these statistical data reveal that YouTube users choose the right videos to watch for exercises for knee OA and contribute to guiding other users by using like, dislike, and comment functions. Therefore, when choosing videos, users can consider the number of views, likes, dislikes, and comments as criteria for determining video quality. It has been reported that showing exercises to the patients in a video is equivalent to personal training with a therapist and provides the necessary feedback for the patient (33). From this perspective, YouTube's potential for therapeutic approaches is remarkable, given the convenience of use, ease of access, cost-effectiveness, and quality of videos. We believe that it is beneficial and convenient for patients and doctors in clinical practice that $60 \%$ of the videos on exercises are high-quality, which is the most important therapeutic approach for knee OA. This study has strengths, such as being the first study to analyze exercise treatments in knee OA and a satisfactory number of analyzed exercise videos as well as some limitations. The first and most important limitation of the study is related to the video searching phase. Videos have been searched on YouTube cross-sectionally and in a single geographic location. Considering this website is continuously updated with new videos each day, and search localization and previous activities affect the results, our findings are only a reflection of instantaneous data, not global results. However, these problems are not specific to this study and are the general challenge of such studies. Secondly, only English language videos were included in this study. The inclusion of different languages in the search would change the results. Last but not least, the exercise content in the videos was not evaluated in this study. If this evaluation has been made and the videos have also been grouped according to the exercise content, it would be possible to have more detailed data.

\section{Conclusion}

YouTube can be considered a source of quality and reliable content in terms of exercise videos related to knee OA treatment. Physicians who have the potential to produce high-quality videos should be encouraged to create more videos. Studies in which the proposed exercise types are also examined, including videos in languages other than English would introduce new perspectives to the literature.

\section{Ethics}

Ethics Committee Approval: This study did not include any humans or animals; therefore, we did not apply for ethical approval or register for clinical trials.

Informed Consent: The study does not require patient consent. Peer-review: Externally peer-reviewed.

\section{Authorship Contributions}

Surgical and Medical Practices: F.B., E.Y., M.H.T., Concept: F.B., E.Y., M.H.T., Design: F.B., E.Y., M.H.T., Data Collection or Processing: F.B., E.Y., M.H.T., Analysis or Interpretation: F.B., E.Y., M.H.T., Literature Search: F.B., E.Y., M.H.T., Writing: F.B., E.Y., M.H.T.

Conflict of Interest: No conflict of interest was declared by the authors.

Financial Disclosure: The authors declared that this study has received no financial support.

\section{References}

1. Güler Uysal F, Başaran S. Knee Osteoarthritis. Turk J Phys Med Rehab 2009;55 Suppl 1:1-7.

2. Tuncer T, Cay FH, Altan L, Gurer G, Kacar C, Ozcakir S, et al. 2017 update of the Turkish League Against Rheumatism (TLAR) evidence-based recommendations for the management of knee osteoarthritis. Rheumatol Int 2018;38:1315-31.

3. Bosomworth NJ. Exercise and knee osteoarthritis: benefit or hazard? Can Fam Physician 2009;55:871-8.

4. Bossen D, Veenhof C, Van Beek KE, Spreeuwenberg PM, Dekker J, De Bakker DH. Effectiveness of a web-based physical activity intervention in patients with knee and/or hip osteoarthritis: randomized controlled trial. J Med Internet Res 2013;15:e257. 
5. Chen HM, Hu ZK, Zheng XL, Yuan ZS, Xu ZB, Yuan LQ, et al Effectiveness of YouTube as a Source of Medical Information on Heart Transplantation. Interact J Med Res 2013;2:e28.

6. Ho M, Stothers L, Lazare D, Tsang B, Macnab A. Evaluation of educational content of YouTube videos relating to neurogenic bladder and intermittent catheterization. Can Urol Assoc J 2015;9:320-54.

7. Rössler B, Lahner D, Schebesta K, Chiari A, Plöchl W. Medical information on the Internet: Quality assessment of lumbar puncture and neuroaxial block techniques on YouTube. Clin Neurol Neurosurg 2012;114:655-8.

8. Allen M, lezzoni LI, Huang A, Huang L, Leveille SG. Improving patient-clinician communication about chronic conditions: description of an internet-based nurse E-coach intervention. Nurs Res 2008;57:107-12.

9. Nason K, Donnelly A, Duncan HF. YouTube as a patient-information source for root canal treatment. Int Endod J 2016;49:1194-200.

10. Steinberg PL, Wason S, Stern JM, Deters L, Kowal B, Seigne J. YouTube as source of prostate cancer information. Urology 2010;75:619-22

11. Madathil KC, Rivera-Rodriguez AJ, Greenstein JS, Gramopadhye AK. Healthcare information on YouTube: A systematic review. Health Informatics J 2015;21:173-94.

12. Pandey A, Patni N, Singh M, Sood A, Singh G. YouTube as a source of information on the H1N1 influenza pandemic. Am J Prev Med 2010;38:e1-3.

13. Sood A, Sarangi S, Pandey A, Murugiah K. YouTube as a source of information on kidney stone disease. Urology 2011;77:558-62.

14. Pathak R, Poudel DR, Karmacharya P, Pathak A, Aryal MR, Mahmood M, et al. YouTube as a Source of Information on Ebola Virus Disease. N Am J Med Sci 2015;7:306-9.

15. Rittberg R, Dissanayake $T$, Katz SJ. A qualitative analysis of methotrexate self-injection education videos on YouTube. Clin Rheumatol 2016;35:1329-33

16. Bernard A, Langille M, Hughes S, Rose C, Leddin D, Veldhuyzen van Zanten S. A systematic review of patient inflammatory bowel disease information resources on the World Wide Web. Am J Gastroenterol 2007;102:2070-7.

17. Charnock D, Shepperd S, Needham G, Gann R. DISCERN: an instrument for judging the quality of written consumer health information on treatment choices. J Epidemiol Community Health 1999;53:105-11.

18. Tolu S, Yurdakul OV, Basaran B, Rezvani A. English-language videos on YouTube as a source of information on self-administe subcutaneous anti-tumour necrosis factor agent injections. Rheumatol Int 2018;38:1285-92.

19. Nason GJ, Kelly P, Kelly ME, Burke MJ, Aslam A, Giri SK, et al. YouTube as an educational tool regarding male urethral catheterization. Scand J Urol 2015;49:189-92.
20. Williams D, Sullivan SJ, Schneiders AG, Ahmed $O H$, Lee $H$, Balasundaram AP, et al. Big hits on the small screen: an evaluation of concussion-related videos on YouTube. $\mathrm{Br} J$ Sports Med 2014;48:107-11.

21. Tian Y. Organ donation on Web 2.0: content and audience analysis of organ donation videos on YouTube. Health Commun 2010;25:238-46.

22. Gokcen HB, Gumussuyu G. A Quality Analysis of Disc Herniation Videos on YouTube. World Neurosurg 2019:S1878-8750(19)302463.

23. Kuru T, Erken HY. Evaluation of the Quality and Reliability of YouTube Videos on Rotator Cuff Tears. Cureus 2020;12:e6852.

24. Cassidy JT, Fitzgerald E, Cassidy ES, Cleary M, Byrne DP, Devitt $\mathrm{BM}$, et al. YouTube provides poor information regarding anterior cruciate ligament injury and reconstruction. Knee Surg Sports Traumatol Arthrosc 2018;26:840-5.

25. Kocyigit BF, Nacitarhan V, Koca TT, Berk E. YouTube as a source of patient information for ankylosing spondylitis exercises. Clin Rheumatol 2019;38:1747-51.

26. Wong M, Desai B, Bautista M, Kwon O, Kolodychuk N, Chimento $G$. YouTube is a poor source of patient information for knee arthroplasty and knee osteoarthritis. Arthroplast Today 2018;5:7882.

27. Erdem MN, Karaca S. Evaluating the Accuracy and Quality of the Information in Kyphosis Videos Shared on YouTube. Spine (Phila Pa 1976) 2018;43:E1334-E9.

28. Koller U, Waldstein W, Schatz KD, Windhager R. YouTube provides irrelevant information for the diagnosis and treatment of hip arthritis. Int Orthop 2016;40:1995-2002.

29. Kunze KN, Krivicich LM, Verma NN, Chahla J. Quality of Online Video Resources Concerning Patient Education for the Meniscus: A YouTube-Based Quality-Control Study. Arthroscopy 2020;36:2338.

30. Jones M, Wiberg A. Evaluating Youtube as A Source of Patient Information on Dupuytren's Disease. World J Plast Surg 2017;6:396-8

31. MacLeod MG, Hoppe DJ, Simunovic N, Bhandari M, Philippon MJ, Ayeni OR. YouTube as an information source for femoroacetabular impingement: a systematic review of video content. Arthroscopy 2015;31:136-42.

32. Delli K, Livas C, Vissink A, Spijkervet FK. Is YouTube useful as a source of information for Sjögren's syndrome? Oral Dis 2016;22:196-201

33. Berkoff DJ, Krishnamurthy K, Hopp J, Stanley L, Spores K, Braunreiter D. CORRECTED ERROR VIDEO VERSUS A PHYSICAL THERAPIST INSTRUCTED HOME EXERCISE PROGRAM: ACCURACY OF PERFORMING THERAPEUTIC SHOULDER EXERCISES. Int J Sports Phys Ther 2016;11:757-64. 